DOI 10.18551/rjoas.2021-12.19

\title{
ANALYSIS OF MACRO NUTRITION (NPK) IN SLUDGE PALM OIL MILL EFFLUENT THROUGH TREATMENT WITH NATURAL COAGULANTS OF MORINGA SEED (MORINGA OLEIFERA)
}

\author{
Hamsyin* \\ Postgraduate Program of Management of Natural Resources and the Environment, \\ University of Lambung Mangkurat, Banjarbaru, Indonesia \\ Salamiah \\ Faculty of Agriculture, University of Lambung Mangkurat Banjarbaru, Indonesia
}

Mijani Rahman

Faculty of Fisheries and Marine, University of Lambungangkurat Banjarbaru, Indonesia

Fakhrur Razie

Faculty of Agriculture, University of Lambung Mangkurat Banjarbaru, Indonesia

*E-mail: hamsyinhamsyin99@gmail.com

\begin{abstract}
The content of macro nutrients consisting of $\mathrm{N}, \mathrm{P}, \mathrm{K}$ in Sludge Palm Oil Mill Effluent (SPOME) which has been treated with Moringa seed powder as a coagulant must first be known, as a consideration for its use as organic fertilizer presence does not affect soil fertility and must be available in sufficient and balanced conditions in the growing media. The macronutrients observed consisted of $\mathrm{N}$-Total, $\mathrm{P}$-Total and $\mathrm{K}$-Total. The experimental design used is a nested pattern design (nested design). The experimental results showed that: increasing the dose of Moringa powder caused the $\mathrm{N}$-Total content of POME mud. The increase has a very strong correlation. This can be seen from the value of $r=0.94$. this condition is forgotten because this plant is a legume which is capable of fixing $\mathrm{N}$ from the air; The relationship between Moringa seed powder and the increase in total $\mathrm{P}$ content in the sludge was very strong and tended to increase, indicated by the value of $r=0.88$. This increase was because Moringa seed powder had a fairly high $\mathrm{P}$ content of around $1.17 \%$; changes in the total $\mathrm{K}$ content, in relation to the increase in the dose of Moringa powder showed a positive correlation trend, the higher the dose given the tendency to increase the total $\mathrm{K}$ content in POME mud this correlation was classified as very strong because it had a value of $r=0.83$.
\end{abstract}

\section{KEY WORDS}

Sludge palm oil mill effluent (SPOME), moringa seed powder, macro nutrients.

Oil palm (Elaeis guineensis) is one of the main commodities of Indonesian plantation crops as a foreign exchange earner. The expansion of oil palm plantations has the potential to provide economic benefits, but can result in environmental disturbances (Utami et al., 2017). On the other hand, this industry is one of the largest sources of waste in Indonesia. This is because in the process of producing CPO (Crude Palm Oil) the palm oil plantation industry always produces liquid waste called Palm Oil Mill Effluent (POME). In general, POME has a characteristic temperature of between $60^{\circ} \mathrm{C}-8{ }^{\circ} \mathrm{C}, \mathrm{pH} 3.3$ to 4.6 , thick, brown in color, solids content, contains oil and fat, as well as high COD and BOD. Palm oil mills produce an average of 0.7-1 m3. POME for every tonne of fresh fruit bunches.

POME contains large amounts of Calcium, Magnesium, Nitrogen and Potassium, so it can be used as fertilizer. There are several ways that are worth considering overcoming the problems that exist in the liquid palm oil waste. This is in order to prevent environmental pollution. One way is to use poly aluminum chloride (PAC) as a coagulant. PAC is a 
coagulant commonly used in industrial waste treatment processes. These chemical compounds have the potential to be used as a coagulant for various industrial wastes. PAC has various advantages, namely low corrosivity, the resulting floc is easier to separate, and the $\mathrm{pH}$ of the treated water is not too low (Budiman et al., 2008). Besides that, PAC also has a strong absorption rate, has adhesive strength, has a fast sedimentation rate, has a wide scope of use, and is used fairly at low concentrations (Hutomo, 2015). However, even though PAC has several advantages, the material also has some risks to the environment. Aluminum ions produced by the hydrolysis of PAC can interfere with human health. This causes people who drink water containing high concentrations of $\mathrm{Al}$ ions from PAC to suffer from anemia, hair loss and brain dementia. Given these risks, it is appropriate to consider the use of organic coagulant materials that can be considered environmentally friendly. Utami (2012) stated that Moringa seeds can be used as one of the alternative natural coagulants available locally.

The coagulation effectiveness of Moringa seeds is determined by the cationic protein content. The advantage of using natural coagulants such as Moringa seed powder is that these plants are easy to find in tropical climates. In addition, natural coagulants can form flocs that are stronger against friction during turbulent flow than chemical coagulants. Based on these considerations, the Moringa seeds are worthy of being considered as one of the organic materials suitable for use as a natural coagulant for the purification of Palm Oil Mill Effluent (POME).

This study aims to determine the effective dose of Moringa seed powder on several nutrient parameters $(\mathrm{N}, \mathrm{P}, \mathrm{K})$ in $\mathrm{POME}$ sludge as an organic fertilizer.

\section{METHODS OF RESEARCH}

The experimental design used in this study is a Nested Design. The first factor is the type of coagulator (A), namely Moringa seed powder, while the second factor is the dose of coagulation (B) namely: $1.0 \mathrm{~g} / \mathrm{liter} ; 2.1 \mathrm{~g} / \mathrm{liter}$; $3.2 \mathrm{~g} / \mathrm{liter} ; 4.3 \mathrm{~g} / \mathrm{liter} ; 5.4 \mathrm{~g} / \mathrm{liter})$. The treatment combination was repeated three times so that 15 (fifteen) samples were obtained. In detail the combination of the number of treatments and replications can be seen in the following table:

Table 1 - Results of Combination between Coagulator and Dosage of Treatment on Palm Oil Waste Sludge

\begin{tabular}{|c|c|c|}
\hline \multirow{2}{*}{ Dosage (g) } & \multirow{2}{*}{ Test } & Coagulator \\
\hline & & Chitosan \\
\hline \multirow[t]{3}{*}{0} & R1 & K-0-R1 \\
\hline & $\mathrm{R} 2$ & K-0-R2 \\
\hline & R3 & K-0-R3 \\
\hline \multirow[t]{3}{*}{1} & R1 & K-1-R1 \\
\hline & $\mathrm{R} 2$ & K-1-R2 \\
\hline & R3 & K-1-R3 \\
\hline \multirow[t]{3}{*}{2} & R1 & K-2-R1 \\
\hline & R2 & K-2-R2 \\
\hline & R3 & K-2-R3 \\
\hline \multirow[t]{3}{*}{3} & R1 & K-3-R1 \\
\hline & $\mathrm{R} 2$ & K-3-R2 \\
\hline & R3 & K-3-R3 \\
\hline \multirow[t]{3}{*}{4} & R1 & K-4-R1 \\
\hline & R2 & K-4-R2 \\
\hline & R3 & K-4-R3 \\
\hline
\end{tabular}

Note: $K=$ Moringa, $P=$ Treatment, $R=$ Repeat .

The research procedure begins with separating the liquid waste from the sludge by pipetting the Palm Oil Mill Effluent slowly and placing 15 glass cups. Coagulant according to the dose is put into the glass, and then filtered to take the sludge. Analysis of nutrient content in sludge is carried out in the laboratory, nutrient parameters and analytical methods can be seen in the following table: 
Table 2 - Method of Analysis of Nutrient Parameters in Sludge Palm Oil Mill Effluent (SPOME)

\begin{tabular}{|l|l|l|l|l|}
\hline No & Parameter & Unit & Analysis/Measurement Method & Sample Source \\
\hline 1 & Nitrogen & $(\%)$ & Kjeldahl & Sludge Waste \\
\hline 2 & P-available and K-available & $\mathrm{ppm}$ & Extraction Bray 1 & Sludge Waste \\
\hline
\end{tabular}

The data collected from the results of this study will be tested by statistical methods with the $\mathrm{F}$ test (at the level of accuracy of $5 \%$ and $1 \%$ ). Furthermore, if the results of the $\mathrm{F}$ test indicate a significant difference as a result of the research treatment, it will be continued with the BNT test (smallest significant difference) at the 5\% level.

\section{RESULTS AND DISCUSSION}

Test results Nutrient content of Sludge Palm Oil Mill Effluent that has been treated with Moringa seed powder.

The test results on the treatment of Moringa seed powder on the N-Total sludge value can be seen in the following table and figure:

Table 3 - Effect of Different Doses of Moringa (Moringa oleifera) Seed Powder on N-Total Sludge (\%) POME

\begin{tabular}{|l|l|l|l|l|l|l|}
\hline \multirow{2}{*}{ No. } & \multirow{2}{*}{ Treatments } & \multicolumn{2}{l}{ Test (\%) } & \multirow{2}{*}{ Amount } & \multirow{2}{*}{ average } \\
\cline { 3 - 6 } & & R1 & R2 & R3 & & \\
\hline 1. & Moringa Powder 0 g (P0) & 1.18 & 1.05 & 0.98 & 3.21 & $1.07^{\mathrm{a}}$ \\
\hline 2. & Moringa Powder 1 g (P1) & 1.34 & 1.43 & 1.34 & 4.11 & $1.37^{\mathrm{D}}$ \\
\hline 3. & Moringa Powder 2 g (P2) & 1.21 & 1.34 & 1.45 & 4.00 & $1.33^{\mathrm{b}}$ \\
\hline 4. & Moringa Powder 3 g (P3) & 1.56 & 1.59 & 1.87 & 5.02 & $1.67^{\mathrm{C}}$ \\
\hline 5. & Moringa Powder 4 g (P4) & 1.67 & 1.76 & 1.67 & 5.10 & $1.70^{\mathrm{C}}$ \\
\hline
\end{tabular}

Note: Numbers followed by the same letter in the same column are not significantly different in the 5\% BNT test.

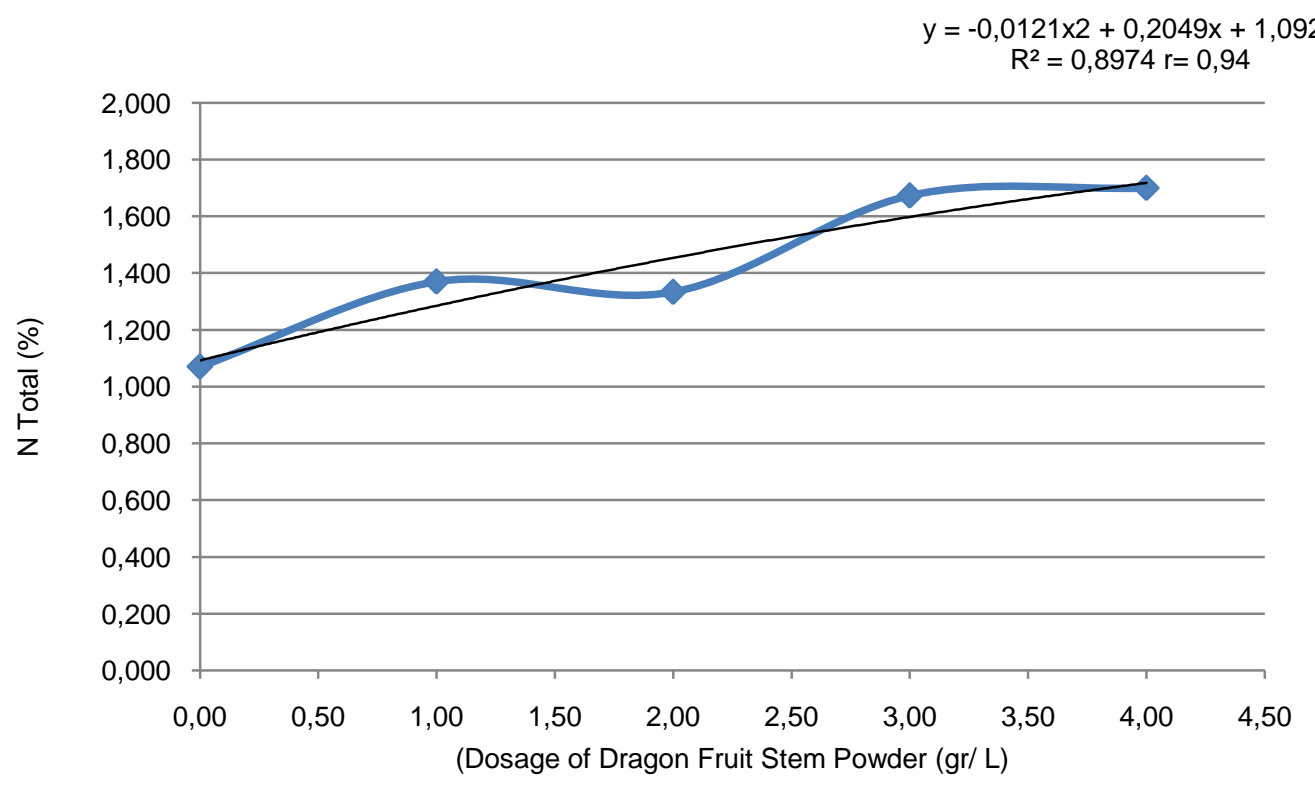

Figure 1 - Relationship between Moringa Seed Powder Dose Increase and Change in N-Total Sludge POME Value

Seen in Table 3 above, it shows that the highest value of $\mathrm{N}$-Total sludge was found in the P4 treatment (Kloring seed powder $4.00 \mathrm{~g} / \mathrm{L}$ ) with a value of $1.70 \%$. This value was not significantly different from the P3 treatment (Kelor seed powder $3.00 \mathrm{~g} / \mathrm{L}$ ). While the smallest value of $\mathrm{N}$-Total sludge was found in the $\mathrm{P} 0$ treatment (without Moringa powder) with a value of $1.07 \%$. This treatment was significantly different from all existing treatments. Based on Figure 1 above, it can be seen that the addition of a dose of Moringa powder caused an 
increase in the $\mathrm{N}$-Total sludge POME content. The increase has a very strong correlation. This can be seen from the value of $r=0.94$. This condition is thought to be because this plant is a legume plant which is able to fix $\mathrm{N}$ from the air. This is in line with the opinion (Sari and Prayudyaningsih, 2015) which states that Moringa is a type of legume that can be used as a source of protein, the protein compounds are mainly composed of the nutrient $\mathrm{N}$.

The test results on the treatment of Moringa seed powder on the P-Total sludge value can be seen in the following table and figure:

Table 4 - Effect of Different Doses of Moringa (Moringa oleifera) Seed Powder on Total P Content in POME Sludge

\begin{tabular}{|l|l|l|l|l|l|l|}
\hline \multirow{2}{*}{ No. } & \multirow{2}{*}{ Treatments } & Test (\%) & \multirow{2}{*}{ Amount } & \multirow{2}{*}{ Average } \\
\cline { 3 - 6 } & & R1 & R2 & R3 & & \\
\hline 1. & Moringa Powder 0 g (P0) & 0.25 & 0.45 & 0.58 & 1.28 & $0.43^{\mathrm{a}}$ \\
\hline 2. & Moringa Powder 1 g (P1) & 0.54 & 0.34 & 0.32 & 1.21 & $0.40^{\mathrm{a}}$ \\
\hline 3. & Moringa Powder 2 g (P2) & 0.45 & 0.41 & 0.35 & 1.22 & $0.41^{\mathrm{a}}$ \\
\hline 4. & Moringa Powder 3 g (P3) & 0.52 & 0.45 & 0.32 & 1.29 & $0.43^{\mathrm{a}}$ \\
\hline 5. & Moringa Powder 4 g (P4) & 0.35 & 0.64 & 0.32 & 1.32 & $0.44^{\mathrm{a}}$ \\
\hline
\end{tabular}

Note: Numbers followed by the same letter in the same column are not significantly different in the $5 \%$ BNT test.

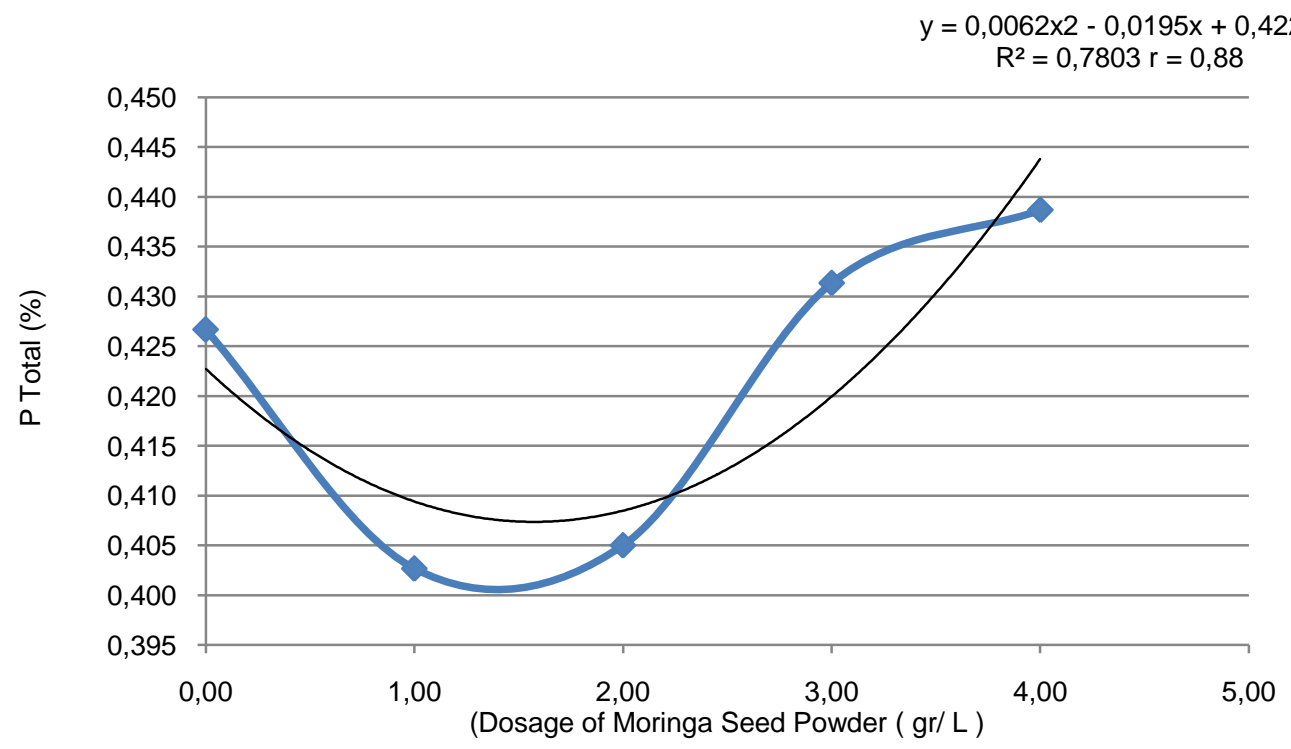

Figure 2 - Relationship between Moringa Powder Dose Increase and Changes in Total P Content in Sludge POME

Based on Table 4 above, it can be seen that the effect of treatment with Moringa seed powder on the $P$ value of total sludge showed the highest concentration was found in $\mathrm{P} 4$ treatment $(4.00 \mathrm{~g} / \mathrm{L})$ with a value of $0.44 \%$. The treatment was not significantly different from all other treatments. While the lowest value was found in the P1 treatment (moringa powder $1.004 .00 \mathrm{~g} / \mathrm{L}$ ) with a value of $0.40 \%$, where the treatment was also not significantly different from all other treatments. Based on Table 19 shows that the average total $P$ value in the sludge is around $0.40 \%$. Based on Figure 2 above, it can be seen that the pattern of changes in total sludge $\mathrm{P}$ concentration tends to decrease from $\mathrm{PO}$ treatment (without Moringa powder) then increases again in P2 treatment $(2.00 \mathrm{~g} / \mathrm{L}$ Moringa powder) to P4 treatment (4.00 g/L Moringa powder). L). The figure also shows that the relationship between the addition of Moringa seed powder to the increase in total $P$ content in the sludge is very strong and tends to increase. This is indicated by the value of $r=0.88$. This increase was because Moringa seed powder had a fairly high $\mathrm{P}$ content of around $1.17 \%$. This causes the moringa to be potentially used for fertilizer (Adiaha, 2017).

The results of the analysis of the effect of Moringa seed powder on the total $\mathrm{K}$ content in POME sludge are visually shown in the following table and figure: 
Table 5 - The Effect of Different Doses of Moringa Seed Powder (Moringa oleifera) on Total K Content in POME Sludge

\begin{tabular}{|l|l|l|l|l|l|l|}
\hline \multirow{2}{*}{ No. } & \multirow{2}{*}{ Treatments } & \multicolumn{2}{l}{ Test (\%) } & \multirow{2}{*}{ Amount } & \multirow{2}{*}{ average } \\
\cline { 3 - 6 } & & R1 & R2 & R3 & & \\
\hline 1. & Moringa Powder 0 g (P0) & 0.53 & 0.62 & 0.49 & 1.64 & $0.55^{\mathrm{a}}$ \\
\hline 2. & Moringa Powder 1 g (P1) & 0.50 & 0.45 & 0.61 & 1.56 & $0.52^{\mathrm{a}}$ \\
\hline 3. & Moringa Powder 2 g (P2) & 0.57 & 0.58 & 0.61 & 1.76 & $0.59^{\mathrm{a}}$ \\
\hline 4. & Moringa Powder 3 g (P3) & 0.60 & 0.71 & 0.54 & 1.85 & $0.62^{\mathrm{a}}$ \\
\hline 5. & Moringa Powder 4 g (P4) & 0.72 & 0.57 & 0.53 & 1.82 & $0.61^{\mathrm{a}}$ \\
\hline
\end{tabular}

Note: Numbers followed by the same letter in the same column are not significantly different in the $5 \%$ BNT test.

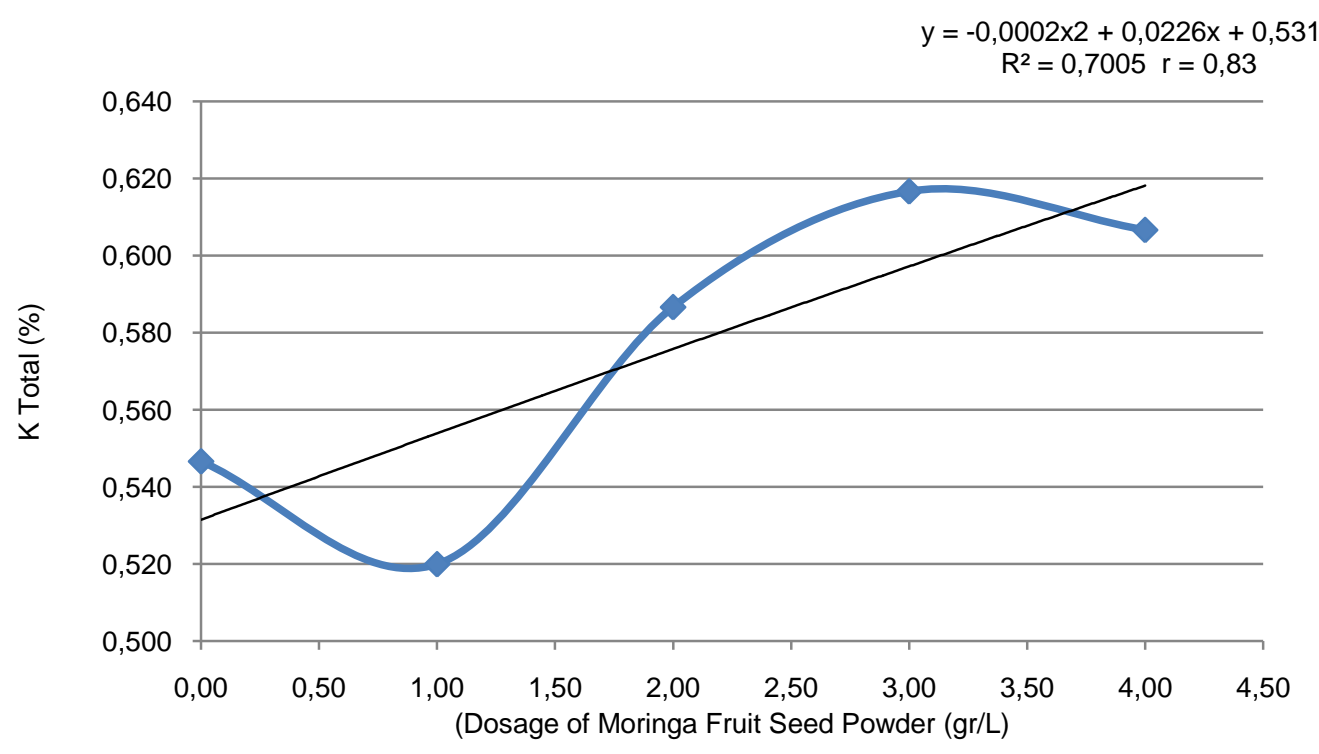

Figure 3 - The Relationship between the Dose Of Moringa Seed Powder And The Content Of Total K in Sludge Solution POME

From Table 5, it can be seen that the highest value of total $\mathrm{K}$ solubility in POME sludge was found in the P3 treatment $(3.00 \mathrm{~g} / \mathrm{L}$ Moringa powder) with a value of $0.62 \%$. While the lowest value was found in treatment P1 (moringa powder $1.00 \mathrm{~g} / \mathrm{L}$ ) with a value of $0.52 \%$. From the data above it also shows that none of these treatments were significantly different from one another. This shows that the administration of Moringa seed powder at a dose of $0.00 \mathrm{~g} / \mathrm{L}$ to $4 \mathrm{~g} / \mathrm{L}$ does not statistically affect the $\mathrm{K}$ content of the total sludge POME. This condition is presumably because the main source of total $\mathrm{K}$ measured is the content of the sludge itself which is sourced from palm organic matter. This is in line with that reported by Nur rizki et al. (2019) which states that oil palm sludge is very potential to be used for fertilizer because it contains sufficient nutrients such as N, P and K. Based on Figure 3, it can be seen that changes in total $\mathrm{K}$ content, in relation to the increase in the dose of Moringa powder, show a tendency to be positively correlated. This means that the higher the dose given has a tendency to increase the total $\mathrm{K}$ content in the POME sludge. This correlation is classified as very strong because it has a value of $r=0.83$. This is presumably because Moringa seed powder has a high content of $\mathrm{K}$ element so that it has an influence on the pattern of increasing the total K content in POME sludge. Reported by Rani et al. (2019) that the element $\mathrm{K}$ content in Moringa pods is about $260 \mathrm{mg}$ in every $100 \mathrm{~g}$.

\section{CONCLUSION}

The experimental results showed that the treatment of Moringa seed powder with different doses on POME sludge seen in the content of the N-Total value of the sludge showed that the highest $\mathrm{N}$-Total value occurred in P4 treatment with a dose of $4 \mathrm{~g}$ Moringa seed powder with an $\mathrm{N}$-Total value of $1,70 \%$ and the lowest occurred in the P0 treatment 
with a dose of $0 \mathrm{~g}$ Moringa seed powder with a total $\mathrm{N}$-value of $1.07 \%$; The highest P-Total content occurred in treatment P4 with a dose of $4 \mathrm{~g}$ Moringa seed powder with a dose of $4 \mathrm{~g}$ with a P-Total value of $0.44 \%$ and the lowest P-Total occurred in P1 treatment with a dose of 0.40 Moringa seed powder. \%; The K-Total content in POME sludge showed that the highest $\mathrm{K}$-Total value occurred in P3 treatment with a dose of $3 \mathrm{~g}$ Moringa seed powder with a KTotal value of $0.62 \%$ and the lowest occurred in P1 treatment with a dose of $1 \mathrm{~g}$ with a K value. -Total $0.52 \%$.

\section{REFERENCES}

1. Adiaha, M.S., 2017. Potential of Moringa oleifera as nutrient-agent for biofertilizer production.WNOFNS. 10 (2017):101-104.

2. Budiman, A., C. Wahyudi, W. Irawati. dan H. Hindarso. 2008. KinerjaKoagulan Poly Aluminium Chloride (PAC) DalamPenjernihan Air Sungai Kalimas Surabaya Menjadi Air Bersih.Jurnal WidyaTeknik. 7(1): $25-34$.

3. Hutomo, S.W.S. 2015.Keefektifan Dosis Poly Alumunium Chloride (Pac) Dalam Menurunkan Kadar Phosphate Pada Air Limbah Laundry Di GatakGede, Boyolali. Naskah Publikasi. Program Studi Kesehatan Masyarakat Fakultas IImu Kesehatan Universitas Muhammadiyah Surakarta. Surakarta. $13 \mathrm{~h}$.

4. Utami, R., E.I. Kumala. dan M. Ekayani. 2017. Dampak Ekonomi dan Lingkungan Ekspansi Perkebunan Kelapa Sawit (StudiKasus: Desa Penyabungan, Kecamatan Merlung, KabupatenTanjung Jabung Barat, Jambi). Jurnal IImu Pertanian Indonesia (JIPI). 22 (2): $115-126$.

5. Sari, R.K.,L. Tinadan A.F.Fachlevy(2017). Efektifitas Biji Kelor (MoringaOleifera) Terhadap Bakteri Escherichia Coli Dalam Upaya Pencegahan Penyakit Diare.JurnalllmiahKesehatanMasyarakatUnsiyah. 2(6): 6-7.

6. Nur rizki dkk. (2019), Prosiding Semnas Pertanian 2019. Fakultas Pertanian Universitas Mulawarman, Samarinda.

7. Rani dkk. (2019) Modul Pelatihan. Kandungan Nutrisi Tanaman Kelor. Fakultas Farmasi. Universitas Surabaya. 2019. 